\title{
Retained Placenta in Relation with Blood Components in Egyptian Crossbred Cattle
}

\author{
Mourad RS \\ Animal Production Department, Faculty of Agriculture, Menoufia University, Egypt \\ E-mail: efaidallah@gmail.com
}

(received: 20-07-2019; revised: 10-08-2019; accepted: 09-09-2019)

\begin{abstract}
ABSTRAK
Mourad RS. 2019. Retensiplasentadanhubungannyadengankomponendarahpadasapimesirpersilangan. JITV 24(3): 103-111 DOI: http://dx.doi/10.14334/jitv.v24i3.2002

Retained placenta (RP) adalah salah satu gangguan reproduksi utama pada sapi perah dan terjadi jika plasenta tidak dilepaskan dalam kurun waktu kurang lebih 12 jam setelah melahirkan dan 3 jam setelah pembukaan. Penelitian ini dilakukan pada 14 sapi normal dan 32 sapi dengan RP di unit dokter hewan. Sapi yang dipilih adalah sapi betina dalam masa nifas selama kurang lebih 6 hingga 12 jam di Menoufia, Mesir. Hasil penelitian menunjukkan bahwa terdapat peningkatan yang signifikan pada konsentrasi komponen darah pada sapi normal dibandingkan dengan sapi yang mengalami RP, kecuali pada globulin, sodium dan mangan. Konsentrasi plasma komponen biokimia menunjukkan hasil yang signifikan antara musim panas dan musim dingin pada kolesterol, total protein dan albumin tetapi tidak ada perbedaan pada glukosa, globulin dan A/Grasio. Konsentrasi plasma lebih tinggi di musim dingin dari pada di musim panas di semua elemen makro kecuali kalium dan rasio $\mathrm{Ca} / \mathrm{P}$. Juga, konsentrasi plasma lebih tinggi di musim dingin dari pada di musim panas di semua elemen mikro kecuali mangan. Konsentrasi plasma komponen biokimia tidak signifikan antara paritas kecuali dalam rasio A/G. Tidak ada konsentrasi plasma yang signifikan antara musim panas dan musim dingin di semua elemen makro. Tetapi, ada perbedaan yang signifikan $(\mathrm{P} \leq 0,01)$ dalam konsentrasi plasma $\mathrm{Cu}$ dan $\mathrm{Cd}$ antara musim panas dan musim dingin, dan ada perbedaan yang signifikan $(\mathrm{P} \leq 0,05)$ pada Fe dan Se tetapi, tidak ada yang signifikan dalam Co, Zn, Mn, dan Mo.
\end{abstract}

Kata Kunci: Sapi, Mineral Makro-Mikro, Konstituen Plasma, Retensi Plasenta

\begin{abstract}
Mourad RS. 2019. Retained placenta in Relation with Blood Components in Egyptian crossbred cattle. JITV 24(3): 103-111. DOI: http://dx.doi/10.14334/jitv.v24i3.2002

Retained placenta (RP) is one of the main reproductive disorders in dairy cattle and happened if the placenta is not released out within certain duration around $12 \mathrm{~h}$ post calving and $3 \mathrm{~h}$ post foaling. The present study was carried out in the veterinary units on 14 normal cows and 32 cows with RP. Cows were chosen after about 6 to $12 \mathrm{~h}$ from parturition in Menoufia governorate, Egypt. Results show that there was significant increase of concentrations of blood components in normal cows than those in RP cows except in globulin, sodium and manganese. Plasma concentrations of biochemical components were significant between summer and winter in cholesterol, total protein and albumin but it was no difference in glucose, globulin and A/G ratio. Plasma concentration is higher in winter than in summer in all macro elements except potassium and $\mathrm{Ca} / \mathrm{P}$ ratio. Also, Plasma concentration is higher in winter than in summer in all micro elements except Manganese. Plasma concentrations of biochemical components were not significant between parities except in $\mathrm{A} / \mathrm{G}$ ratio. No significant in plasma concentration between summer and winter in all macro elements. But, there was significant deference $(\mathrm{P} \leq 0.01)$ in plasma concentration of $\mathrm{Cu}$ and $\mathrm{Cd}$ between summer and winter, and it was significant deference $(\mathrm{P} \leq 0.05)$ in $\mathrm{Fe}$ and Se but, there was no significant in $\mathrm{Co}, \mathrm{Zn}, \mathrm{Mn}$, and $\mathrm{Mo}$.
\end{abstract}

Key Words: Cattle, Macro-Micro-Minerals, Plasma Constituents, Retained Placenta

\section{INTRODUCTION}

Retained placenta (RP) is one of the main reproductive disorders in dairy cattle. That causes economic losses in the herd due to decreased milk production, illness and treatment cost, beside a decreased market value of the animal (Semacan \& Sevinç 2005). Fetal membranes "placenta" is a vital organ for prenatal transfer of nutrients, oxygen and immunity from the mother to the fetus. It is normally released in the short time post parturition. The RP as a reproductive disorder 
happened if the placenta is not released within certain duration around 12 hours post calving and 3 hours post foaling (Mohamed \& Amer 2009; Taylor et al. 2010).

The risk factors associated with RP include twins, dystocia, stillborn calf, induced parturition, abortion, milk fever, and increasing age, as well as conflicting seasonal effects (Gröhn \& Rajala-Schultz 2000). Metabolic disorders play an important role in pathology of puerperal period. Deficiency of energy often causes the atony or hypotony of the uterus and this is the main cause of its late involution and cleaning. Energy disturbances can start a few weeks before calving (Kuzma et al. 1996). Cows with RP have to increased uterine activity in the days after calving (Frazer 2005). The incidence of retained placenta in dairy cattle averages around $4 \%$ and appears to be worsening (Esslemont \& Kossaibati 2002). Cows with RP have an increased risk of metritis within one month postpartum and longer days to first service and services per conception (Correa et al. 1993). Other causes of RP as: genetic and breed predisposition, time of calving, length of pregnancy and the age of cows (Laven \& Peters 1996). There is a fluctuation in the occurrence of RP in the same herd in different years and among herds in the same year. The interesting is that high milk efficiency in the previous lactation is not a risk factor of placental retention (Gröhn et al. 1995). The aim of this study was to determine blood plasma components in case of RP in Egyptian crossbred cattle.

\section{MATERIALS AND METHODS}

This study was carried out in veterinary units in Shebin El-kom, Menoufia, Egypt. 46 postpartum crossbred cows aged from 4 to 11 years, 345 to $620 \mathrm{~kg}$ live body weight and within the 2 to 6 parity were subjected in this study. There is influence between various parities. The experimental cows included fourteen normal cows as a control group and thirty two cows with RP. Cows were chosen after about 6 to 12 hours from parturition. Cows rations consisted of a commercial concentrate feed mixture as $60 \%$ yellow corn, $15 \%$ wheat bran, $23 \%$ soybean meal, $1 \% \mathrm{NaCL}$ and $1 \%$ mineral mixtures, green clover (Trifolium alexandrinum) and rice straw, Animals were milked twice daily morning and evening milking.

Blood samples collected from jugular vein into clean heparinized test tubes were centrifuged at $3000 \mathrm{rpm}$ for 20 minutes, then blood plasma was carefully separated and stored frozen at $-20^{\circ} \mathrm{C}$. Plasma digested by adding 10 $\mathrm{ml}$ concentrate $\mathrm{H} 2 \mathrm{SO} 4$ and two drops of $\mathrm{H}_{2} \mathrm{O}_{2}$ to $1 \mathrm{ml}$ of blood plasma and heated. The digested sample diluted with distillated water at a ratio of 1:50. Concentration of macro- (Na, K, Mg, and Ca) and micro- (Mn, $\mathrm{Cd}, \mathrm{Se}, \mathrm{Co}$, $\mathrm{Cu}, \mathrm{Mo}, \mathrm{Fe}$, and $\mathrm{Zn}$ ) elements were determined from blood plasma using an atomic absorption spectrophotometer "Unicam 929 AA". However, concentration of cholesterol, glucose, total protein, albumin, and inorganic phosphorus was determined calorimetrically according to (Allain et al.). Concentration of globulin was calculated by subtracting albumin and total protein concentration.

Data obtained were statistically analyzed using descriptive statistics, ANOVA and Duncan test was used to determine the significant differences among means at $\alpha=0.05$ via SAS computer program (SAS 2003).

\section{RESULTS AND DISCUSSION}

\section{Blood Biochemistry of cattle with normal and retained placenta}

\section{Biochemical components}

Concentration of blood biochemical components including cholesterol $(\mathrm{CH})$, glucose $(\mathrm{G})$, total protein (TP), albumin (AL), globulin (GL), AL/GL ratio and are depicted in Table 1.

Results showed that there were very highly significant increases in all concentrations of blood biochemical components in normal cows than those in retained fetal membranes cows except in globulin (GL). Time around calving is a critical period in high-yielding cows with regard to hormonal changes, metabolism, immunity, health, further fertility, and milk productivity (LeBlanc 2013). During the time of retained fetal membranes, the immune system is depressed in periparturient cows (Goff 2008).

Normal blood serum metabolic in cows were as following: glucose ranged from 3 to $4 \mathrm{mmol} / \mathrm{l}$, albumin ranged from 30 to $49 \mathrm{~g} / \mathrm{l}$ and, cholesterol ranged from 1.8 to $5.2 \mathrm{mmol} / \mathrm{l}$ (Winnicka 1997).

Glucose level decreasing cause decreased the activity of aspartate aminotransferase during the last month of pregnancy so it is the main factor in happening of RP (Markiewicz et al. 2001).

Cows with retained placenta had glucose $(\mathrm{RP}=1.99 \pm$ 0.80 , Normal $=2.35 \pm 0.67 \mathrm{mmol} / \mathrm{l})$ and cholesterol $(\mathrm{RP}=$ $2.08 \pm 0.83$, Normal $=2.17 \pm 0.84 \mathrm{mmol} / \mathrm{l}$ ) levels similar to the lower limit of physiological normal $(2.22 \mathrm{mmol} / \mathrm{l}$ of glucose and $2.33 \mathrm{mmol} / \mathrm{l}$ of cholesterol) (Kaczmarowski et al. 2006). There was no significant difference in the serum total protein between buffalo cows with RP and normal parturient buffalo cows (Dutta and Dugwekar 1983). 
Mourad RS. Retained placenta in Relation with Blood Components in Egyptian crossbred cattle

Table 1. Blood biochemical components in normal and RP crossbred cattle

\begin{tabular}{|c|c|c|c|c|c|c|}
\hline Biochemical components & Case & Mean & $\pm \mathrm{SE}$ & Min & Max & P Value \\
\hline \multirow{2}{*}{ Cholesterol (mg/dl) } & Normal & 214.45 & \pm 0.59 & 210.30 & 218.10 & 0.00 \\
\hline & $\mathrm{RP}$ & 170.77 & \pm 6.35 & 128.71 & 231.71 & \\
\hline \multirow{2}{*}{ Glucose (mg/dl) } & Normal & 74.75 & \pm 0.71 & 72.59 & 78.65 & 0.00 \\
\hline & $\mathrm{RP}$ & 42.90 & \pm 0.79 & 38.99 & 51.79 & \\
\hline \multirow{2}{*}{ Total protein (mg/dl) } & Normal & 7.25 & \pm 0.14 & 6.38 & 7.68 & 0.00 \\
\hline & $\mathrm{RP}$ & 5.96 & \pm 0.08 & 5.00 & 6.67 & \\
\hline \multirow{2}{*}{ Albumin (mg/dl) } & Normal & 6.08 & \pm 0.1 & 5.48 & 6.35 & 0.00 \\
\hline & $\mathrm{RP}$ & 4.65 & \pm 0.07 & 4.02 & 5.54 & \\
\hline \multirow{2}{*}{ Globulin (mg/dl) } & Normal & 1.17 & \pm 0.05 & 0.90 & 1.33 & 0.30 \\
\hline & $\mathrm{RP}$ & 1.31 & \pm 0.09 & 0.40 & 2.05 & \\
\hline \multirow{2}{*}{ A/G Ratio } & Normal & 5.29 & \pm 0.2 & 4.71 & 6.61 & 0.00 \\
\hline & $\mathrm{RP}$ & 1.29 & \pm 0.02 & 1.09 & 1.47 & \\
\hline
\end{tabular}

Normal $=14$ healthy cows, $\mathrm{RP}=32$ cows with retained placenta. Significant different at $(\mathrm{P} \leq 0.05)$

Table 2a. Blood plasma macro elements in normal and RP crossbred cattle.

\begin{tabular}{|c|c|c|c|c|c|c|c|c|c|c|c|c|}
\hline Case & Macro & $\begin{array}{r}\text { Mean } \\
\quad(\mathrm{m} \xi\end{array}$ & $\begin{array}{l}\text { SE } \\
\text { dl) }\end{array}$ & Min & Max & $\begin{array}{c}\text { P- } \\
\text { Value }\end{array}$ & Macro & \multicolumn{2}{|c|}{$\begin{array}{c}\text { Mean } \pm \mathrm{SE} \\
(\mathrm{mg} / \mathrm{dl})\end{array}$} & Min & Max & $\begin{array}{c}\text { P- } \\
\text { Value }\end{array}$ \\
\hline Normal & \multirow{2}{*}{$\mathrm{Na}$} & 147.09 & \pm 0.58 & 143.89 & 149.56 & 0.11 & $\mathrm{Ca}$ & 10.46 & \pm 0.24 & 9.14 & 12.02 & \multirow{2}{*}{0.00} \\
\hline $\mathrm{RP}$ & & 159.07 & \pm 4.81 & 140.28 & 215.30 & & & 8.08 & \pm 0.19 & 6.45 & 10.30 & \\
\hline Normal & \multirow{2}{*}{ K } & 6.23 & \pm 0.15 & 5.23 & 7.20 & 0.00 & $\mathrm{P}$ & 5.46 & \pm 0.16 & 4.60 & 6.40 & \multirow{2}{*}{0.00} \\
\hline $\mathrm{RP}$ & & 32.47 & \pm 0.29 & 29.00 & 36.55 & & & 4.69 & \pm 0.08 & 4.18 & 5.57 & \\
\hline Normal & \multirow{2}{*}{$\mathrm{Mg}$} & 5.4600 & \pm 0.09 & 4.91 & 5.72 & 0.00 & $\mathrm{Ca} / \mathrm{P}$ & 1.92 & \pm 0.04 & 1.61 & 2.00 & \multirow{2}{*}{0.00} \\
\hline $\mathrm{RP}$ & & 2.4195 & \pm 0.14 & 2.01 & 4.10 & & Rat1o & 1.72 & \pm 0.02 & 1.30 & 1.94 & \\
\hline
\end{tabular}

Normal $=14$ healthy cows, $\mathrm{RP}=32$ cows with retained placenta. Significant different at $(\mathrm{P} \leq 0.05)$

Table 2b. Blood plasma micro elements in normal and RP crossbred cattle.

\begin{tabular}{|c|c|c|c|c|c|c|c|c|c|c|c|c|}
\hline Case & Micro & \multicolumn{2}{|c|}{$\begin{array}{c}\text { Mean } \pm \text { SE } \\
(\mu \mathrm{g} / \mathrm{dl})\end{array}$} & Min & Max & $\begin{array}{c}\text { P- } \\
\text { Value }\end{array}$ & Micro & \multicolumn{2}{|c|}{$\begin{array}{c}\text { Mean } \pm \text { SE } \\
(\mu \mathrm{g} / \mathrm{dl})\end{array}$} & Min & Max & $\begin{array}{c}\mathrm{P}- \\
\text { Value }\end{array}$ \\
\hline Normal & \multirow{2}{*}{$\mathrm{CO}$} & 4.46 & \pm 0.07 & 3.89 & 4.65 & 0.00 & $\mathrm{Se}$ & 0.59 & \pm 0.01 & 0.58 & 0.66 & \multirow{2}{*}{0.00} \\
\hline $\mathrm{RP}$ & & 2.72 & \pm 0.04 & 2.15 & 2.89 & & & 0.39 & \pm 0.00 & 0.36 & 0.45 & \\
\hline Normal & \multirow{2}{*}{$\mathrm{CU}$} & 0.82 & \pm 0.05 & 0.65 & 1.13 & 0.00 & $\mathrm{Fe}$ & 4.21 & \pm 0.10 & 3.68 & 4.72 & \multirow{2}{*}{0.00} \\
\hline $\mathrm{RP}$ & & 0.41 & \pm 0.01 & 0.35 & 0.45 & & & 6.06 & \pm 0.31 & 2.95 & 8.00 & \\
\hline Normal & \multirow{2}{*}{$\mathrm{Zn}$} & 1.26 & \pm 0.14 & 0.66 & 1.84 & 0.00 & Mo & 0.14 & \pm 0.00 & 0.13 & 0.15 & \multirow{2}{*}{0.00} \\
\hline $\mathrm{RP}$ & & 0.88 & \pm 0.03 & 0.43 & 1.00 & & & 0.03 & \pm 0.00 & 0.02 & 0.03 & \\
\hline Normal & \multirow{2}{*}{$\mathrm{Mn}$} & 0.35 & \pm 0.02 & 0.20 & 0.45 & 0.12 & $\mathrm{Cd}$ & 0.89 & \pm 0.11 & 0.49 & 1.54 & \multirow{2}{*}{0.00} \\
\hline $\mathrm{RP}$ & & 0.42 & \pm 0.03 & 0.08 & 0.56 & & & 0.42 & \pm 0.00 & 0.40 & 0.46 & \\
\hline
\end{tabular}

Normal $=14$ healthy cows, $\mathrm{RP}=32$ cows with retained placenta. Significant different at $(\mathrm{P} \leq 0.05)$ 


\section{Macro and Micro-Elements}

Concentration of blood macro- and micro- elements in plasma of normal cows and those with retained fetal membranes are shown in Table $2 \mathrm{a}$ and $2 \mathrm{~b}$. Results showed that concentrations of all blood macro elements were statistically higher in normal cows than those with retained fetal membranes except $\mathrm{Na}$ and $\mathrm{K}$ elements. Also there was a very highly significant difference $(\mathrm{P} \leq 0.01)$ between all macro elements in normal cows and those with retained fetal membranes except in $\mathrm{Na}$.

In high yielding cows, the most important pathogenic factor causing RP during parturition is immune suppression caused by metabolic disorders. These metabolic conditions and health effects are adequately connected with high milk production in cows (Goff 2008).

Serum $\mathrm{Ca}$ and blood glucose levels were significantly lower $(\mathrm{P}<0.01)$ in buffaloes with retention of fetal membrane than normal parturient buffaloes. They suggested that the lower $\mathrm{Ca}$ concentration and lower energy level might be responsible for the occurrence of retention of fetal membranes in buffaloes (Mandali et al. 2002).

The disturbance in the $\mathrm{Ca}$ metabolism and its utilization by the tissue results in atony of the internal organs. Moreover, during advanced stages of pregnancy, there is excessive mobilization of $\mathrm{Ca}$, then less availability of glucose and $\mathrm{Ca}$ to the uterine tissues results in atony of the uterus, with decreased contraction and RP (Mohanty et al. 1994). In addition, immune-mediated etiology of mineral disturbances observed especially during hypocalcaemia - milk fever in dairy cows (Kimura et al. 2006; Gray et al. 2007).

Table $2 \mathrm{~b}$ showed that plasma concentrations of $\mathrm{Co}$, $\mathrm{Cu}, \mathrm{Zn}, \mathrm{Se}, \mathrm{Mo}$, and $\mathrm{Cd}$ in normal cows were higher than those with retained fetal membranes. On the other hand, the blood plasma concentrations of $\mathrm{Mn}$, and $\mathrm{Fe}$ were statistically higher in cows with retained fetal membranes than in those normal cows. Also there was a very highly significant difference $(\mathrm{P} \leq 0.01)$ between all micro elements in normal cows and those with retained fetal membranes except in Mn.

The oxidative stress and its immune-suppressive consequences also in relation to RP are caused not only by deficiency of vitamins $\mathrm{E}$ and $\mathrm{A}$, but also by a lack of micro- or macro-elements such as $\mathrm{Se}, \mathrm{Zn}, \mathrm{Cu}$, and $\mathrm{Cr}$ in diet (Kendall and Bone 2006). Copper is essential for normal phagocytosis (Spears and Weiss 2008).

Blood serum metabolic and mineral limits in cows as follows: glucose (3-4 mmol/l), albumins (30-49 g/l), $\mathrm{Mg}$ (> $0.7 \mathrm{mmol} / \mathrm{l}), \mathrm{P}(>1.3 \mathrm{mmol} / \mathrm{l})$, for Normal cows and
Ca $(2.4-3.0 \mathrm{mmol} / \mathrm{l})$, cholesterol $(1.8-5.2 \mathrm{mmol} / \mathrm{l})$, may be helpful during potential biochemical blood metabolic monitoring in dairy cows in terms of RP (Winnicka 1997). In addition; the normal limits for the most important trace elements in serum as $\mathrm{Cu}(9.2 \mu \mathrm{mol} / \mathrm{l})$, I (3-6 $\mu \mathrm{g} / \mathrm{l})$, Mo $(>1.1 \mu \mathrm{mol} / \mathrm{l})$, Fe $(25-35 \mu \mathrm{mol} / \mathrm{l})$, Co $(0.38-1.85 \mu \mathrm{mol} / \mathrm{l})$ or in plasma as $\mathrm{Se}(>110 \mu \mathrm{g} / \mathrm{l}), \mathrm{Zn}$ (80-120 $\mu \mathrm{g} / \mathrm{dl})$, Mn (5-6 $\mu \mathrm{g} / \mathrm{l})$ (Mordak et al. 2017).

Se deficiency is associated with an increased risk of retained placenta and perhaps mastitis. It is thought that Se deficiency reduces the immune response in the cow. The mechanisms are largely unknown (Erickson et al. 2015). Sedependant glutathione peroxidase (GSHPx) has been found to be associated with the incidence of RP with low levels in plasma being reported with higher incidence of RP (Brzezinska-Slebodzinska et al. 1994). Vitamin E and Se supplementation of dairy cows, concluding that supplementing diets with both or either alone could reduce the risk of RP (Mee 2004). The use of inorganic Se may indeed prevent severe Se deficiencies but supplementation with Se yeast proved beneficial in providing enhanced Se status and antioxidant function at times of greatest stress and disease challenge, such as in the periparturient period (Givens et al. 2004).

\section{Effect of season on the occasion of retained placenta in cattle}

Table 3 showed that plasma concentrations of biochemical components were highly significant $(\mathrm{P} \leq 0.01)$ between summer and winter in cholesterol, total protein and albumin but was no difference in between the two seasons in the concentrations of glucose, globulin and $\mathrm{A} / \mathrm{G}$ ratio. Effect of season is also significant according to temperature and nutrition (Cady 2008).

The season is correlated with birth weight of calves. Extremely low and high temperatures affect birth weight (Deutscher et al. 1999). The distribution of retained placenta in cattle as following: $27.5 \%$ cases occurred in spring, $32.5 \%$ in summer, $7.5 \%$ in autumn and $32.5 \%$ in winter (Sharma et al. 2017).

Table $4 \mathrm{a}$ shows that there is very highly significant different $(\mathrm{P} \leq 0.01)$ in plasma concentration between summer and winter in all macro elements except $\mathrm{K}$ and $\mathrm{Ca} / \mathrm{P}$ ratio. The incidence of $\mathrm{RP}$ varies from $4-16.1 \%$ in cow and it can be much higher in problem herds. It increases during summer with increased parity and following birth of male fetus (El-Malky et al. 2010).

There were no significant differences in RP percentage between winter and summer feeding as well as between male or female birthing (Gaafar et al. 2010). Other causes of RP as time of calving "more frequent 
Mourad RS. Retained placenta in Relation with Blood Components in Egyptian crossbred cattle

Table 3. Seasonal variations of blood biochemical components day in crossbred cattle with RP

\begin{tabular}{|c|c|c|c|c|c|c|}
\hline Items & Case & Mean & $\pm \mathrm{SE}$ & Min & $\operatorname{Max}$ & P-Value \\
\hline \multirow{2}{*}{ Cholesterol (mg/dl) } & Summer & 168.33 & \pm 7.38 & 128.71 & 231.71 & \multirow{2}{*}{0.00} \\
\hline & Winter & 206.42 & \pm 3.49 & 181.71 & 217.25 & \\
\hline \multirow{2}{*}{ Glucose $(\mathrm{mg} / \mathrm{dl})$} & Summer & 49.09 & \pm 2.81 & 38.99 & 77.90 & \multirow{2}{*}{0.06} \\
\hline & Winter & 57.57 & \pm 3.52 & 39.00 & 78.65 & \\
\hline \multirow{2}{*}{ Total protein (mg/dl) } & Summer & 6.07 & \pm 0.11 & 5.00 & 7.23 & \multirow{2}{*}{0.00} \\
\hline & Winter & 6.76 & \pm 0.18 & 5.99 & 7.68 & \\
\hline \multirow{2}{*}{ Albumin (mg/dl) } & Summer & 4.76 & \pm 0.11 & 4.02 & 6.28 & \multirow{2}{*}{0.00} \\
\hline & Winter & 5.55 & \pm 0.16 & 4.53 & 6.35 & \\
\hline \multirow{2}{*}{ Globulin (mg/dl) } & Summer & 1.31 & \pm 0.09 & 0.40 & 2.05 & \multirow{2}{*}{0.41} \\
\hline & Winter & 1.21 & \pm 0.07 & 0.75 & 1.70 & \\
\hline \multirow{2}{*}{ A/G Ratio } & Summer & 2.36 & \pm 0.38 & 1.09 & 6.61 & \multirow{2}{*}{0.54} \\
\hline & Winter & 2.72 & \pm 0.41 & 1.14 & 4.77 & \\
\hline
\end{tabular}

Summer $(\mathrm{n}=27)$, Winter $(\mathrm{n}=19)$. Significant different at $(\mathrm{P} \leq 0.05)$

Table 4a. Seasonal variations of plasma macro elements in crossbred cattle with RP

\begin{tabular}{|c|c|c|c|c|c|c|c|c|c|c|c|c|}
\hline Case & Macro & $\begin{array}{r}\text { Mean } \pm \\
(\mathrm{mg} /\end{array}$ & & Min & $\operatorname{Max}$ & $\begin{array}{c}\mathrm{P}- \\
\text { Value }\end{array}$ & Macro & \multicolumn{2}{|c|}{$\begin{array}{c}\text { Mean } \pm \text { SE } \\
(\mathrm{mg} / \mathrm{dl})\end{array}$} & Min & Max & $\begin{array}{c}\text { P- } \\
\text { Value }\end{array}$ \\
\hline Summer & \multirow{2}{*}{$\mathrm{Na}$} & 147.19 & \pm 0.71 & 140.28 & 155.01 & 0.00 & $\mathrm{Ca}$ & 8.39 & \pm 0.30 & 6.45 & 12.02 & \multirow{2}{*}{0.02} \\
\hline Winter & & 167.13 & \pm 7.57 & 140.28 & 215.30 & & & 9.39 & \pm 0.28 & 7.45 & 10.30 & \\
\hline Summer & \multirow{2}{*}{$\mathrm{K}$} & 26.93 & \pm 2.19 & 5.23 & 36.55 & \multirow[t]{2}{*}{0.12} & \multirow[t]{2}{*}{$\mathrm{P}$} & 4.76 & \pm 0.12 & 4.18 & 6.40 & \multirow{2}{*}{0.03} \\
\hline Winter & & 21.01 & \pm 2.98 & 5.87 & 32.92 & & & 5.16 & \pm 0.13 & 4.35 & 6.10 & \\
\hline Summer & \multirow{2}{*}{$\mathrm{Mg}$} & 2.73 & \pm 0.26 & 2.01 & 5.68 & \multirow[t]{2}{*}{0.00} & \multirow{2}{*}{$\begin{array}{l}\mathrm{Ca} / \mathrm{P} \\
\text { Ratio }\end{array}$} & 1.76 & \pm 0.03 & 1.30 & 1.99 & \multirow{2}{*}{0.21} \\
\hline Winter & & 4.22 & \pm 0.34 & 2.04 & 5.72 & & & 1.82 & \pm 0.03 & 1.61 & 2.00 & \\
\hline
\end{tabular}

Summer $(\mathrm{n}=27)$, Winter $(\mathrm{n}=19)$. Significant different at $(\mathrm{P} \leq 0.05)$

Table 4b. Seasonal variations of plasma micro elements in crossbred cattle with RP

\begin{tabular}{|c|c|c|c|c|c|c|c|c|c|c|c|c|}
\hline Case & Micro & \multicolumn{2}{|c|}{$\begin{array}{c}\text { Mean } \pm \text { SE } \\
(\mu \mathrm{g} / \mathrm{dl})\end{array}$} & Min & Max & $\begin{array}{c}\text { P- } \\
\text { Value }\end{array}$ & Micro & \multicolumn{2}{|c|}{$\begin{array}{c}\text { Mean } \pm \text { SE } \\
(\mu \mathrm{g} / \mathrm{dl})\end{array}$} & Min & Max & $\begin{array}{c}\text { P- } \\
\text { Value }\end{array}$ \\
\hline Summer & \multirow{2}{*}{$\mathrm{CO}$} & 3.15 & \pm 0.12 & 2.82 & 4.58 & 0.00 & $\mathrm{Se}$ & 0.43 & \pm 0.01 & 0.360 & 0.579 & \multirow{2}{*}{0.00} \\
\hline Winter & & 3.38 & \pm 0.25 & 2.15 & 4.65 & & & 0.50 & \pm 0.02 & 0.400 & 0.660 & \\
\hline Summer & \multirow{2}{*}{$\mathrm{CU}$} & 0.52 & \pm 0.05 & 0.35 & 1.13 & 0.00 & $\mathrm{Fe}$ & 6.22 & \pm 0.28 & 3.68 & 8.00 & \multirow{2}{*}{0.00} \\
\hline Winter & & 0.55 & \pm 0.03 & 0.44 & 0.86 & & & 4.49 & \pm 0.37 & 2.95 & 6.94 & \\
\hline Summer & \multirow{2}{*}{$\mathrm{Zn}$} & 0.89 & \pm 0.03 & 0.43 & 1.00 & 0.00 & Mo & 0.05 & \pm 0.01 & 0.026 & 0.149 & \multirow{2}{*}{0.00} \\
\hline Winter & & 1.14 & \pm 0.12 & 0.59 & 1.84 & & & 0.07 & \pm 0.01 & 0.023 & 0.143 & \\
\hline Summer & \multirow{2}{*}{$\mathrm{Mn}$} & 0.46 & \pm 0.02 & 0.20 & 0.56 & 0.12 & $\mathrm{Cd}$ & 0.57 & \pm 0.05 & 0.40 & 1.11 & \multirow{2}{*}{0.00} \\
\hline Winter & & 0.31 & \pm 0.04 & 0.08 & 0.52 & & & 0.57 & \pm 0.08 & 0.41 & 1.54 & \\
\hline
\end{tabular}


during spring and summer". There is a fluctuation in the occurrence of RP in the same herd in different years and among herds in the same year (Laven \& Peters 1996).

Table $4 \mathrm{~b}$ illustrated that there was very highly significant $(\mathrm{P} \leq 0.01)$ in plasma concentration between summer and winter in all micro elements except Mn.

The highest percentages of incidence of RP were detected in spring and summer seasons, while the lowest percentage was noticed in autumn. Furthermore, they reported that the causes of the lower incidence in the fall season compared to hot season are due to the environmental and nutritional differences, e.g. temperature and concentrate to forage ration in the diet (Sharma et al. 2017).

\section{Effect of parity on Retained Placenta incidence in cattle}

Table 5 shows that plasma concentrations of biochemical components were not significant between parities except in $\mathrm{A} / \mathrm{G}$ ratio was significant $(\mathrm{P} \leq 0.05)$. Retained placenta was highly significant in pleuriparous than primiparous cows (Sharma et al. 2017). The incidence of retained placenta increased in old cows with parity over fourth (Gabr et al. 2005).

The incidence of RP varies from $4-16.1 \%$ in cow and it can be much higher in problem herds. It increases during summer with increased parity and following birth of male fetus (El-Malky et al. 2010). Other causes of RP as the age of cows "more frequent in older animals". There is a fluctuation in the occurrence of RP in the same herd in different years and among herds in the same year (Laven and Peters 1996).

Table 6a showed that there was no significant in plasma concentration among parities in all macro elements except in $\mathrm{Na}$ was significant $(\mathrm{P} \leq 0.05)$.

The incidence of RP at $1^{\text {st }}$ parity, $2^{\text {nd }}$ parity, $3^{\text {rd }}$ parity, $4^{\text {th }}$ parity, $5^{\text {th }}$ parity and $>6^{\text {th }}$ parity were $8.5 \%, 13.3 \%$, $6.1 \%, 9.4 \%, 20 \%$ and $28.7 \%$, respectively (Sarder et al. 2010). The incidence of RP in Friesian cows increased significantly from first parity to eighth parity (Gaafar et al. 2010). The rates of retention of placenta in first were equal to second but they were less than third and fifth parity (Azad 2010).

Table 5. Effect of parity on blood biochemical components day in crossbred cattle with RP

\begin{tabular}{|c|c|c|c|c|c|c|}
\hline Items & Parity & Mean & $\pm \mathrm{SE}$ & Min & Max & P- Value \\
\hline \multirow[t]{4}{*}{ Cholesterol (mg/dl) } & $2^{\text {nd }}$ & 191.60 & \pm 11.26 & 131.00 & 231.71 & \multirow{4}{*}{0.06} \\
\hline & $3^{\text {rd }}$ & 191.38 & \pm 6.89 & 129.50 & 231.71 & \\
\hline & $\geq 4$ & 163.12 & \pm 10.12 & 128.71 & 214.55 & \\
\hline & $2^{\text {nd }}$ & 59.45 & \pm 5.76 & 39.00 & 78.65 & \\
\hline \multirow[t]{2}{*}{ Glucose (mg/dl) } & $3^{\text {rd }}$ & 51.91 & \pm 3.00 & 38.99 & 78.65 & \multirow[t]{2}{*}{0.18} \\
\hline & $\geq 4$ & 47.64 & \pm 3.43 & 39.29 & 72.60 & \\
\hline \multirow[t]{4}{*}{ Total protein $(\mathrm{mg} / \mathrm{dl})$} & $2^{\text {nd }}$ & 6.31 & \pm 0.24 & 5.29 & 7.42 & \multirow{4}{*}{0.64} \\
\hline & $3^{\text {rd }}$ & 6.45 & \pm 0.14 & 5.50 & 7.68 & \\
\hline & $\geq 4$ & 6.20 & \pm 0.25 & 5.00 & 7.68 & \\
\hline & $2^{\text {nd }}$ & 5.23 & \pm 0.24 & 4.02 & 6.28 & \\
\hline \multirow[t]{3}{*}{$\operatorname{Albumin}(\mathrm{mg} / \mathrm{dl})$} & $3^{\text {rd }}$ & 5.14 & \pm 0.16 & 4.02 & 6.35 & \multirow[t]{3}{*}{0.45} \\
\hline & $\geq 4$ & 4.85 & \pm 0.20 & 4.40 & 6.35 & \\
\hline & $2^{\text {nd }}$ & 1.08 & \pm 0.12 & 0.75 & 1.91 & \\
\hline \multirow[t]{3}{*}{ Globulin (mg/dl) } & $3^{\text {rd }}$ & 1.32 & \pm 0.08 & 0.75 & 1.89 & \multirow[t]{3}{*}{0.25} \\
\hline & $\geq 4$ & 1.35 & \pm 0.15 & 0.40 & 2.05 & \\
\hline & $2^{\text {nd }}$ & $3.79 \mathrm{a}$ & \pm 0.75 & 1.17 & 6.61 & \\
\hline \multirow[t]{2}{*}{ A/G Ratio } & $3^{\text {rd }}$ & $2.22 b$ & \pm 0.34 & 1.14 & 5.33 & \multirow[t]{2}{*}{0.03} \\
\hline & $\geq 4$ & $1.88 \mathrm{~b}$ & \pm 0.39 & 1.09 & 4.77 & \\
\hline
\end{tabular}

Number of $2^{\text {nd }}=11,3^{\text {rd }}=23$ and $\geq 4=12$. Significant different at $(\mathrm{P} \leq 0.05)$ 
Mourad RS. Retained placenta in Relation with Blood Components in Egyptian crossbred cattle

Table 6a. Effect of parity on plasma macro elements in crossbred cattle with RP

\begin{tabular}{|c|c|c|c|c|c|c|c|c|c|c|c|c|}
\hline \multirow{2}{*}{$\frac{\text { Parity }}{2^{\text {nd }}}$} & \multirow[t]{2}{*}{ Items } & \multicolumn{2}{|c|}{ Mean $(\mathrm{mg} / \mathrm{dl}) \pm \mathrm{SE}$} & \multirow{2}{*}{$\frac{\text { Min }}{140.28}$} & \multirow{2}{*}{$\frac{\text { Max }}{150.00}$} & \multirow{2}{*}{$\frac{\text { P-Value }}{0.05}$} & \multirow{2}{*}{$\begin{array}{c}\text { Items } \\
\mathrm{Ca}\end{array}$} & \multicolumn{2}{|c|}{ Mean $(\mathrm{mg} / \mathrm{dl}) \pm \mathrm{SE}$} & \multirow{2}{*}{$\begin{array}{l}\text { Min } \\
6.45\end{array}$} & \multirow{2}{*}{$\frac{\operatorname{Max}}{12.02}$} & \multirow[t]{2}{*}{ P-Value } \\
\hline & & $146.38^{\mathrm{b}}$ & \pm 0.92 & & & & & 9.03 & \pm 0.63 & & & \\
\hline $3^{\text {rd }}$ & \multirow[t]{3}{*}{$\mathrm{Na}$} & $163.85^{\mathrm{a}}$ & \pm 6.42 & 140.28 & 215.30 & & & 9.00 & \pm 0.28 & 7.45 & 11.32 & 0.29 \\
\hline$\geq 4$ & & $147.58 b$ & \pm 1.24 & 140.28 & 155.01 & & & 8.21 & \pm 0.32 & 7.42 & 10.29 & \\
\hline $2^{\text {nd }}$ & & 18.48 & \pm 4.33 & 5.23 & 34.60 & 0.12 & & 5.15 & \pm 0.25 & 4.20 & 6.40 & \multirow{3}{*}{0.27} \\
\hline $3^{\text {rd }}$ & \multirow{2}{*}{$\mathrm{K}$} & 25.09 & \pm 2.38 & 5.87 & 33.42 & & \multirow[t]{2}{*}{$\mathrm{P}$} & 4.93 & \pm 0.13 & 4.18 & 6.10 & \\
\hline$\geq 4$ & & 28.82 & \pm 3.07 & 6.35 & 36.55 & & & 4.73 & \pm 0.08 & 4.40 & 5.15 & \\
\hline $3^{\text {rd }}$ & \multirow[t]{2}{*}{$\mathrm{Mg}$} & 3.49 & \pm 0.32 & 2.01 & 5.72 & & \multirow{2}{*}{$\begin{array}{l}\mathrm{Ca} / \mathrm{P} \\
\text { Ratio }\end{array}$} & 1.82 & \pm 0.024 & 1.61 & 2.00 & \multirow[t]{2}{*}{0.21} \\
\hline$\geq 4$ & & 2.63 & \pm 0.41 & 2.01 & 5.65 & & & 1.73 & \pm 0.05 & 1.51 & 2.00 & \\
\hline
\end{tabular}

Number of $2^{\text {nd }}=11,3^{\text {rd }}=23$ and $\geq 4=12$. Significant different at $(\mathrm{P} \leq 0.05)$
Table 6b. Effect of parity on plasma micro elements in crossbred cattle with RP

\begin{tabular}{|c|c|c|c|c|c|c|c|c|c|c|c|c|}
\hline \multirow{2}{*}{$\frac{\text { Parity }}{2^{\text {nd }}}$} & \multirow[t]{2}{*}{ Items } & \multicolumn{2}{|c|}{ Mean $(\mathrm{mg} / \mathrm{dl}) \pm \mathrm{SE}$} & \multirow{2}{*}{$\frac{\text { Min }}{2.82}$} & \multirow{2}{*}{$\begin{array}{l}\text { Max } \\
4.65\end{array}$} & \multirow{2}{*}{$\frac{\text { P-Value }}{0.15}$} & \multirow{2}{*}{$\begin{array}{c}\text { Items } \\
\mathrm{Se}\end{array}$} & \multicolumn{2}{|c|}{ Mean $(\mathrm{mg} / \mathrm{dl}) \pm \mathrm{SE}$} & \multirow{2}{*}{$\frac{\text { Min }}{0.39}$} & \multirow{2}{*}{$\frac{\operatorname{Max}}{0.66}$} & \multirow{2}{*}{$\frac{\text { P-Value }}{0.06}$} \\
\hline & & 3.68 & \pm 0.25 & & & & & 0.50 & \pm 0.03 & & & \\
\hline $3^{\text {rd }}$ & $\mathrm{CO}$ & 3.09 & \pm 0.19 & 2.15 & 4.65 & & & 0.46 & \pm 0.02 & 0.37 & 0.66 & \\
\hline $2^{\text {nd }}$ & & $0.71^{\mathrm{a}}$ & \pm 0.09 & 0.35 & 1.13 & 0.004 & $\mathrm{Fe}$ & 5.67 & \pm 0.56 & 3.68 & 8.00 & 0.06 \\
\hline $3^{\text {rd }}$ & $\mathrm{CU}$ & $0.50^{\mathrm{b}}$ & \pm 0.03 & 0.35 & 0.86 & & & 4.95 & \pm 0.35 & 2.95 & 6.95 & \\
\hline$\geq 4$ & & $0.44^{\mathrm{b}}$ & \pm 0.03 & 0.35 & 0.65 & & & 6.38 & \pm 0.39 & 3.99 & 8.00 & \\
\hline $2^{\text {nd }}$ & & 0.88 & \pm 0.04 & 0.66 & 1.04 & 0.47 & Mo & 0.09 & \pm 0.02 & 0.03 & 0.15 & 0.08 \\
\hline $3^{\text {rd }}$ & $\mathrm{Zn}$ & 1.00 & \pm 0.09 & 0.43 & 1.84 & & & 0.05 & \pm 0.01 & 0.02 & 0.15 & \\
\hline$\geq 4$ & & 1.07 & \pm 0.11 & 0.68 & 1.84 & & & 0.04 & \pm 0.01 & 0.03 & 0.13 & \\
\hline $2^{\text {nd }}$ & & 0.40 & \pm 0.04 & 0.20 & 0.56 & 0.09 & $\mathrm{Cd}$ & $0.82 \mathrm{a}$ & \pm 0.13 & 0.40 & 1.54 & 0.00 \\
\hline $3^{\text {rd }}$ & $\mathrm{Mn}$ & 0.36 & \pm 0.04 & 0.08 & 0.54 & & & $0.52 b$ & \pm 0.05 & 0.40 & 1.54 & \\
\hline$\geq 4$ & & 0.48 & \pm 0.02 & 0.36 & 0.56 & & & $0.43 b$ & \pm 0.01 & 0.41 & 0.49 & \\
\hline
\end{tabular}


Table $6 \mathrm{~b}$ showed that there was very highly significant $(\mathrm{P} \leq 0.01)$ in plasma concentration of $\mathrm{Cu}$ and $\mathrm{Cd}$ between parities, and it was significant $(\mathrm{P} \leq 0.05)$ in $\mathrm{Fe}$ and $\mathrm{Se}$ but, there was no significant in $\mathrm{Co}, \mathrm{Zn}, \mathrm{Mn}$, and Mo. So, the concentration of trace elements decreased with the increased of parity in all trace elements except $\mathrm{Zn}, \mathrm{Mn}$ and $\mathrm{Fe}$.

\section{CONCLUSION}

Retained placenta is failure of expulsion of the placenta and associated membranes within $24 \mathrm{~h}$ of calving. Retained placenta, metritis, and endometritis are diseases of immune function in the transition period, which begin at least 2 weeks pre-partum. It is concluded that retention of placenta is the most important factor leading to uterine infection and toxic puerperal metritis occurring during the early postpartum period. Prevention of retained placenta, of course, is the key of economy loss. In conclusion, plasma minerals and biochemical components are different between control and retained placenta groups. In addition, seasons and parities affected the happenings of fetal membrane retention in cattle.

\section{REFERRENCES}

Allain C, Poon L, Chan C. G. and Richmond, WFC (1974). The Merk manual of diagnostic and therapy, Merk Co. Clin Chem. 20:470-475.

Azad M. 2010. Prevention of retained placenta by injecting various drugs immediately after parturition in cows. (Thesis). Department of surgery and obstetrics, faculty of veterinary.

Brzezinska-Slebodzinska E, Miller J, Quigley III J, Moore J, Madsen F. 1994. Antioxidant status of dairy cows supplemented prepartum with vitamin $\mathrm{E}$ and selenium. J Dairy Sci. 77:3087-3095.

Cady R. 2008. Dystocia-difficult calving, what it costs and how to avoid it. [Durham (USA)]: University of New Hampshire.

Correa M, Erb H, Scarlett J. 1993. Path analysis for seven postpartum disorders of Holstein cows. J Dairy Sci. 76:1305-1312.

Deutscher GH, Colburn D, Davis R. 1999. Climate affects calf birth weights and calving difficulty. [Lincoln (USA)]: University of Nebraska.

Dutta J, Dugwekar Y. 1983. Retention of fetal membranes in buffaloes: serum proteins and blood glucose levels. Indian J Anim Reprod. 4:56-58.

El-Malky O, Youssef M, Abdel Aziz N, El-Salaam A. 2010. Post-partum performance of buffaloes treated with GnRH to overcome the impact of placental retention. J Anim Sci. 6:225-230.

Erickson HH, Goff JP, Uemura EE. 2015. Dukes' physiology of domestic animals. $13^{\text {rd }}$ edition. [New Jersey (USA)]: Wiley-Blackwell.

Esslemont R, Kossaibati M. 2002. The costs of poor fertility and disease in UK dairy herds: trends in DAISY herds over 10 seasons. [Walton (UK)]: Intervet.

Frazer GS. 2005. A rational basis for therapy in the sick postpartum cow. Vet Clin North Am Food Anim Pract. 21:523-568.

Gaafar H, Shamiah SM, Shitta A, Ganah H. 2010. Some factors affecting on retained placenta and its effects on postpartum reproductive performance and milk production of Friesian cows. Slovak J Anim Sci. 43:6-12.

Gabr SA, Shamiah S, Abu-Elhamd M. 2005. Factors related to the incidence of retained placenta in Friesian cows kept under Egyptian conditions. J Agric. Sci. 30.

Givens DI, Allison R, Cottrill B, Blake JS. 2004. Enhancing the selenium content of bovine milk through alteration of the form and concentration of selenium in the diet of the dairy cow. J Sci. Food Agric. 84:811-817.

Goff. 2008. Immune suppression around the time of calving and the impact of metabolic disease. XXV Jubilee World Buiatrics Congress Budapest, Hungry Hungarian Vet J.

Gray C, St George T, Jonsson N. 2007. Milk fever in dairy cattle: A novel hypothesis for an immune mediated aetiology. Cattle Practice. 15:277-282.

Gröhn Y, Eicker S, Hertl J. 1995. The association between previous 305-day milk yield and disease in New York State dairy cows. J Dairy Sci. 78:1693-1702.

Gröhn Y, Rajala-Schultz P. 2000. Epidemiology of reproductive performance in dairy cows. Anim Reprod. Sci. 60:605614.

Kaczmarowski M, Malinowski E, Markiewicz H. 2006. Some hormonal and biochemical blood indices in cows with retained placenta and puerperal metritis. Bull. Vet. Inst. Pulawy. 50:89.

Kendall N, Bone P. 2006. Fertility and trace elements-an underestimated problem. Cattle Practice. 14:17-22.

Kimura K, Reinhardt T, Goff J. 2006. Parturition and hypocalcemia blunts calcium signals in immune cells of dairy cattle. J Dairy Sci. 89:2588-2595.

Kuzma. 1996. Relationship between retained placenta and ketosis in dairy cows. In XIX World Buiatrics Congress, Germany.

Laven R, Peters A. 1996. Bovine retained placenta: aetiology, pathogenesis and economic loss. Vet. Record. 139:465471 . 
LeBlanc S. 2013. Managing transition period health for reproductive performance in dairy cows. Cattle Practice. 21:209-215.

Mandali G, Patel P, Dhami A, Raval S, Chisti K. 2002. Biochemical profile in buffaloes with periparturient reproductive and metabolic disorders. Indian $\mathrm{J}$ Anim Reprod. 23:130-134.

Markiewicz H, Kuzma K, Malinowski E. 2001. Predisposing factors for puerperal metritis in cows. Bull. Vet. Inst. Puławy. 2: 281-288.

Mee J. 2004. The role of micronutrients in bovine periparturient problems. Cattle Practice. 12:95-108.

Mohamed A, Amer A. 2009. Hormonal and biochemical anomalies in dairy cows affected by retained fetal membranes. http: //priory.com/vet/cow_fetal_membrane. htm.

Mohanty K, Mohanty B, Ray S, Mohanty D. 1994. Levels of glucose, calcium and alkaline phosphatase in blood with relation to retention of placenta in bovines. Indian J Anim Reprod. 15:21-23.

Mordak R, Nicpoń J, Illek J. 2017. Metabolic and mineral conditions of retained placenta in highly productive dairy cows: pathogenesis, diagnostics and prevention-a review. Acta Vet Brno. 86:239-248.

Sarder M, Moni M, Aktar S. 2010. Prevalence of reproductive disorders of crossbred cows in the Rajshahi District of Bangladesh. SAARC J Agric. 8:65-75.

SAS. 2003. Statistical Analysis System. SAS Version 9.1. SAS Institute Inc, Cary, NC (USA).

Semacan A, Sevinç M. 2005. Liver function in cows with retained placenta. Turkish J Vet and Anim Sci. 29:775778.

Sharma M, Bhat Y, Sharma N, Rawat S. 2017. Effect of parity of animal and season of the year on the rate of retention of placenta in dairy cattle. I Int J Curr Microbiol Appl Sci. 6:3103-3108.

Spears JW, Weiss WP. 2008. Role of antioxidants and trace elements in health and immunity of transition dairy cows. Vet J. 176:70-76.

Taylor FG, Brazil T, Hillyer MH. 2010. Diagnostic Techniques in Equine Medicine E-Book. [Amsterdam (Netherland): Elsevier Health Sciences.

Winnicka A. 1997. Reference values of basic laboratory tests in veterinary medicine. Wydawnictwo SGGW. 3-115. 